\title{
Preparation of Magnetite by Thermally Induced Decomposition of Ferrous Oxalate Dihydrate in the Combined Atmosphere
}

\author{
Josef Kopp, ${ }^{1}$ Petr Novak, ${ }^{1,}{ }^{\star}$ Josef Kaslik ${ }^{2}$ and Jiri Pechousek ${ }^{1}$ \\ ${ }^{1}$ Department of Experimental Physics, Faculty of Science, Palacký University, 17. listopadu 1192/12, \\ 77146 Olomouc, Czech Republic \\ ${ }^{2}$ Regional Centre of Advanced Technologies and Materials, Palacký University, Šlechtitelì 27, 78371 Olomouc, Czech Republic \\ *Corresponding author: E-mail:petr.novak@upol.cz
}

Received: 01-04-2019

\begin{abstract}
This study presents an investigation of thermal decomposition of ferrous oxalate dihydrate in the combined atmosphere of inert and conversion gases to find an optimal route for a simple magnetite preparation. Homogenized precursor was isothermally treated inside the stainless-steel cells at 8 equidistant temperatures ranging from 300 to $650{ }^{\circ} \mathrm{C}$ for 1,6 , and 12 hours. The enclosure of samples inside the cells with the combined atmosphere eliminates the necessity of the inert gas to flow over the treated samples. Structural, magnetic, and morphological aspects of the prepared materials were examined by the combination of experimental techniques, such as Mössbauer spectroscopy, X-ray powder diffraction, and scanning electron microscopy.
\end{abstract}

Keywords: Mössbauer spectroscopy; XRD; maghemite/magnetite mixture.

\section{Introduction}

Magnetite is a form of an iron oxide, which finds numerous applications in the fields of materials science, information storage, medicine ${ }^{1,2}$ or catalysis (e.g. hydrogenation of $\mathrm{CO}_{2},{ }^{3}$ and water gas shift reaction ${ }^{4}$ ). Since the boom of nanotechnology, the synthesis of magnetite in the form of nanoparticles have been discussed in many studies. ${ }^{5-11}$ Among the methods reported the thermally induced solid state synthesis represents a facile and cost effective method for preparation of iron oxides in the size of nanometres. ${ }^{12,13}$

Ferrous oxalate dihydrate is considered being a versatile precursor for iron oxides preparation. It is a metal organic mineral whose thermal decomposition leads to various forms of oxide, both pure or mixtures. ${ }^{14}$ The individual transformation routes of $\mathrm{FeC}_{2} \mathrm{O}_{4} \cdot 2 \mathrm{H}_{2} \mathrm{O}$ are influenced by many experimental conditions, but the composition of reaction atmosphere, temperature and time of calcination process are among the most important ones. For example, Zhou et al. ${ }^{15}$ reported the use of different reaction atmospheres to prepare rod-like particles composed of different forms of iron oxides.
The thermal decomposition of ferrous oxalate dihydrate in oxygen rich atmosphere (e.g., in air) has been reported in many studies. ${ }^{16-24}$ If the $\mathrm{FeC}_{2} \mathrm{O}_{4} \cdot 2 \mathrm{H}_{2} \mathrm{O}$ is decomposed in air, the reaction is straight-forward and proceeds in two consecutive steps. It was shown that these two steps (endo + exothermal) partially overlap in differential thermal analysis (DTA) in the range up to $450{ }^{\circ} \mathrm{C} .{ }^{19}$ Firstly, approximately at $180^{\circ} \mathrm{C}$ the water evaporates from the crystals; and then the anhydrous ferrous oxalate decomposes to iron oxides. At the temperature of $210{ }^{\circ} \mathrm{C}$ the amorphous ferric oxide is formed. ${ }^{25,26}$ With increased temperature and prolonged calcination, the amorphous ferric oxide transforms to hematite, which is the final product of the reaction. ${ }^{25}$ It is also possible to obtain hematite in mixture with maghemite by employing specific reaction conditions, for example, changing the thickness of the precursor layer and the annealing temperature, which allows to control the hematite/maghemite ratio. ${ }^{19}$ Nanoparticles prepared in a such simple way were reported to have the superior catalytic activity in degradation of hydrogen peroxide. ${ }^{16,27}$ In addition, Rao et al. ${ }^{28}$ reported an occurrence of the maghemite in the composition of the final decomposition product if the 
reaction atmosphere contained a significant amount of moisture.

Another decomposition process was reported to take place under the inert atmosphere (e.g., nitrogen or argon). ${ }^{23,29-33}$ The differential thermal analysis (DTA) of this process generally show two major events in the range up to $450{ }^{\circ} \mathrm{C}$, which are well separated and both of them are endothermic..$^{29}$ The first event corresponds to the evaporation of water molecules $\left(180^{\circ} \mathrm{C}\right)$, while the other one, a large asymmetric peak that starts at approximately $320-350{ }^{\circ} \mathrm{C}$, is attributed to the decomposition of oxalate group and the formation of oxides. One of the generally accepted decomposition mechanisms assumes that the anhydrous ferrous oxalate decomposes to wüstite, which immediately transforms to magnetite and a-iron, due to its instability under $570{ }^{\circ} \mathrm{C} .{ }^{31}$ However, the experimental confirmation of this mechanism is still required, as the formation of wüstite phase has never been observed directly. This mechanism was indirectly supported by the findings in studies ${ }^{31-33}$ which identified magnetite and $\alpha$-iron as major and minor phases of the final product at the temperature up to $550^{\circ} \mathrm{C}$. Another accepted mechanism ${ }^{34}$ assumes that the anhydrous oxalate decomposes directly to ultra-fine magnetite particles with no wüstite intermediate. The two Mössbauer spectroscopy investigations ${ }^{35,36}$ of thermal decomposition of ferrous oxalate dihydrate in the inert atmosphere did not exhibit any formation of $\alpha$-iron, although the experiments as well as Mössbauer measurements were performed inside the glass tube, which prevented the oxidation of small particles of $\alpha$-iron. ${ }^{36}$ Nevertheless, some authors ${ }^{15,37}$ reported completely different composition of the decomposition product in the inert atmosphere. For example, hematite was determined as a major phase of the decomposition in nitrogen at $440{ }^{\circ} \mathrm{C}$ in the study of Mohamed et al. ${ }^{37} \mathrm{In}$ addition, Zhou et al. ${ }^{15}$ reported that the maghemite was the only decomposition product after treating the sample at $400{ }^{\circ} \mathrm{C}$ for $2 \mathrm{~h}$ in nitrogen atmosphere.

A unique study of iron oxalate's decomposition in the atmosphere of its conversion gases was reported by Hermanek et al., ${ }^{34}$ in which both Mössbauer spectroscopy and XRD were used to determine the composition of the samples. The magnetite was reported to be the main product of the thermal decomposition in the temperature range between $400-550{ }^{\circ} \mathrm{C}$. In contrast to Hermanek et al., ${ }^{34}$ the pure magnetite was obtained in three other studies, ${ }^{15,38,39}$ which reported the decomposition of ferrous oxalate dihydrate in the atmosphere of its conversion gases as a very facile method of magnetite preparation. In each of these studies the ferrous oxalate was reported to be sealed inside a container and then calcined for a certain period.

Being aware of the discrepancies concerning the possible contamination of magnetite by other iron phases, in this work we present a systematic study of thermal decomposition of ferrous oxalate in the combined atmosphere of inert and conversion gases to find an optimal synthetic route for magnetite preparation. The usage of conversion gases eliminates the necessity of the inert gas to flow through the furnace thus simplifying the magnetite synthesis process. All the samples were prepared inside the stainless-steel cells. To eliminate the possible effects of residual oxygen on the sample composition, the cells were sealed inside the box with nitrogen atmosphere. The composition and properties of the decomposition products were studied by Mössbauer spectroscopy and XRD.

\section{Experimental Section}

\section{1. Chemicals}

Ferrous Oxalate Dihydrate ( $500 \mathrm{~g}$ ) supplied by Sigma Aldrich was utilized for all the experiments.

\section{2. Synthesis}

The ferrous oxalate dihydrate (Sigma Aldrich) was homogenized in the ceramic mortar for 5 minutes. This process was accompanied by a visible change in the material colour. Approximately $100 \mathrm{mg}$ of homogenized material was enclosed inside each of the prepared sealable stainless-steel cells. The filling of the cells was conducted inside the box with a controlled atmosphere (nitrogen). Once filled and sealed, the cells were put inside the high-temperature laboratory furnace LAC LE/05 with HP40 controller. The decomposition of ferrous oxalate dihydrate and the subsequent formation of magnetite were observed at 8 equidistant temperature steps from $300^{\circ} \mathrm{C}$ to $650^{\circ} \mathrm{C}$ (one step each $50{ }^{\circ} \mathrm{C}$ ). The temperature range was chosen in accordance with the previous thermogravimetric analysis (TGA) or DTA studies performed on the ferrous oxalate dihydrate. ${ }^{23,28,31-34}$ In addition, the samples were calcinated during 3 different time intervals: 1, 6 and 12 hours, for each of the temperature steps, to study the influence of calcination time on properties of the prepared samples. Overall, twenty-four samples with the different temperature and time combinations were prepared. The temperature was measured by both in-built thermometer of the furnace and by an external thermocouple situated in the same place as the sample cell.

\section{3. Characterization}

Transmission ${ }^{57} \mathrm{Fe}$ Mössbauer spectra of the studied samples were measured at room temperature using the MS2007 Mössbauer spectrometer based on virtual instrumentation technique. ${ }^{40,41}$ Constant acceleration mode and ${ }^{57} \mathrm{Co}(\mathrm{Rh})$ source were employed. The Mössbauer spectra were processed by use of MossWinn software program. ${ }^{42}$ The isomer shift values were referred to the value of an $\alpha$-Fe foil sample at room temperature.

All the X-ray diffraction (XRD) patterns were measured by use of the X'PertPRO MPD diffractometer (Malvern Panalytical, Ltd) in the Bragg-Brentano geometry 
equipped with a Co X-ray tube (iron filtered Co Ka radiation: $\lambda=0.178901 \mathrm{~nm}$ ), programmable divergence and diffracted beam anti-scatter slits and a fast X'Celerator detector. The patterns were recorded in the $2 \theta$ range of $5-120^{\circ}$ ( $2 \theta$ resolution of $0.017^{\circ}$ ) at room temperature. Line positions determination and instrumental line broadening evaluation were carried out using commercially available standards SRM640 $(\mathrm{Si})$ and SRM660 $\left(\mathrm{LaB}_{6}\right)$ from the NIST (National Institute of Standard and Technologies). High Score Plus software in conjunction with the PDF-4+ and ICSD databases was employed for crystalline phase identification and Rietveld refinement.

The Scanning electron microscopy (SEM) images were recorded by employing the Scanning electron microscope VEGA3 LMU equipped with Everhart-Thornley type secondary electron detector (TESCAN, Brno, Czech Republic). The accelerating voltage was set to $30 \mathrm{kV}$. The pressure inside the chamber during the measurements was decreased to $10^{-2} \mathrm{~Pa}$ using an in-built rotary vacuum pump.

\section{Results and Discussion}

Before starting, the calcination of homogenized ferrous oxalate dihydrate precursor a portion of it was examined by room temperature Mössbauer spectroscopy. The acquired spectrum exhibited a symmetrical doublet with an isomer shift of $\delta=1.19 \mathrm{~mm} / \mathrm{s}$ and quadrupole splitting of $\Delta E_{\mathrm{Q}}=1.72 \mathrm{~mm} / \mathrm{s}$. Both the spectrum shape and the parameter values are typical for ferrous oxalate dihydrate. ${ }^{23,34}$ The results obtained by XRD and Mössbauer spectroscopy of all 24 prepared samples are presented below. The individual samples are presented within the series, where each of them was prepared at different temperature ( 8 series, 3 samples each). All the samples were labelled $\mathrm{T} x \mathrm{H} y$, where $x$ stands for temperature in ${ }^{\circ} \mathrm{C}$ and $y$ stands for calcination time in hours. The complete list of obtained XRD and Mössbauer results is shown in Table 1. and Table 2., respectively.

\section{1. The T300 Series}

The calcination of the first series of samples was conducted at $300^{\circ} \mathrm{C}$ (i.e., T300 series). The Mössbauer spectrum of the first sample $\mathrm{T} 300 \mathrm{H} 1$ showed an asymmetrical doublet composed of two components. The first one, forming most of the spectrum, was a doublet with hyperfine parameters of $\delta=1.19 \mathrm{~mm} / \mathrm{s}$ and $\Delta E_{\mathrm{Q}}=2.03 \mathrm{~mm} / \mathrm{s}$ that could be assigned to anhydrous ferrous oxalate. In comparison with its hydrated counterpart, the quadrupole splitting was slightly higher, possibly because of the increased asymmetry of the electric field in the surroundings of the iron cations, which was caused by the missing water molecules. The ferrous oxalate doublet formed most of the MS spectrum. The other component was small, singlet resembling doublet with an isomer shift of $\delta=0.33 \mathrm{~mm} / \mathrm{s}$ and quadrupole splitting of $\Delta E_{\mathrm{Q}}=$ $0.45 \mathrm{~mm} / \mathrm{s}$. It possibly originated from the presence of amor- phous iron oxide or superparamagnetic magnetite. The similar doublet was also observed by Hermanek et al., ${ }^{34}$ who identified the doublet as a superparamagnetic magnetite based on low temperature Mössbauer spectroscopy measurements in magnetic field. Due to relative similarity of the observed components we could suggest that the doublet was a superparamagnetic magnetite (SP). The relative area of the smaller doublet component was around $7 \%$. The other two samples of the series were comparable in the sample composition to the first one. The gradual increase up to $13 \%$ in the relative area corresponding to the smaller doublet was observed in the second sample T300H6. Then, in the third sample, it dropped to $8 \%$. However, another component or components, which have the magnetic field, could be observed in a form of small distortions in the background (see Figure 1.) taking roughly $10 \%$ of the relative area. This component or components could be small particles of crystalline magnetite, but they were too small to specify their nature. As it was expected, the calcination of ferrous oxalate at $300{ }^{\circ} \mathrm{C}$ did not result in a complete decomposition of the precursor, but some minor part of it was transformed.

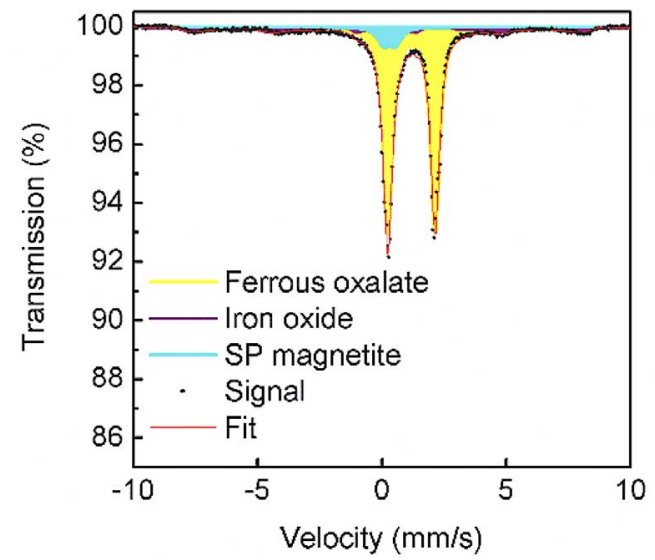

Figure 1. Mössbauer spectrum of T300H12.

\section{2. The T350 Series.}

The temperature $350{ }^{\circ} \mathrm{C}$ used for calcination of the samples of the second series T350 fits well inside the range of the second DTA peak as it was reported in previous works, e.g. ${ }^{31-33}$ The T350 series showed a gradual decomposition of anhydrous ferrous oxalate and formation of crystalline oxides. The Mössbauer spectra of all the three samples of the series exhibited the combination of a doublet and three sextets. The doublet could be again assigned to the remains of the precursor in the sample. Two new sextets were recognised to belong to two different cation sites (i.e., octahedral $(\mathrm{O})$ and tetrahedral $(\mathrm{T})$ ) of a spinel structure of magnetite. The last sextet was ascribed to maghemite, whose presence in the spectra was probably the product of oxidation of nano-sized magnetite, which occurred after the sample cells were opened and the mate- 
rial located inside was exposed to ambient atmosphere. The presence of maghemite in the spectra explains the ratio between the two left-most spectral lines. To distinguish the mixture of magnetite and maghemite from non-stoichiometric magnetite based on Mössbauer spectra is generally very difficult. ${ }^{43}$ To fit all three sextet components, hyperfine parameters of magnetite sub-spectra were allowed to oscillate in a small interval around the fixed previously reported values. ${ }^{44}$ Generally, the maghemite spectra compose of two very similar sextets. ${ }^{44}$ To simplify the overall fit, maghemite was fitted by only one sextet whose hyperfine parameter values could belong only to an interval where the lower and upper limits were chosen to comply with the hyperfine parameters of both maghemite sub-spectra. ${ }^{44}$ Moreover, the ratio between the $\mathrm{O}$ and $\mathrm{T}$ sites of magnetite was firmly fixed at 2:1. The described approach was also employed for all the remaining series. The obtained hyperfine parameters of the samples are shown in Table 2. Compared with T300 series no superparamagnetic magnetite was detected in any of the T350 samples. In contrast with our results, Hermanek et al. ${ }^{34}$ reported that at $363{ }^{\circ} \mathrm{C}$ the doublet of superparamagnetic magnetite formed about $30 \%$ of their Mössbauer spectrum area. Discrepancies could be explained by the absence of the prolonged calcination process in the study. ${ }^{34}$ The evaluation of diffraction patterns of the samples of both T300 and T350 series could be done from qualitative point of view. Although quantitative analysis was also employed for evaluation of all other diffraction patterns, the lack of suitable available patterns with different grade of iron oxalate dihydrate decomposition disabled quantification in this case. Nevertheless, the diffraction patterns displayed relatively broad peaks that could be qualitatively ascribed to anhydrous ferrous oxalate and magnetite. It was observed that the weight ratio of magnetite to oxalate increased with longer calcination and was higher for all the samples in the T350 series compared to the samples of T300 series. By evaluation of both Mössbauer and XRD data of the T350 series, the temperature $350{ }^{\circ} \mathrm{C}$ seemed sufficient for decomposition of the majority of ferrous oxalate and subsequent formation of iron oxides. However, even after $12 \mathrm{~h}$ of calcination a part of the precursor remained undecomposed.

\section{3. The T400 Series}

Regarding the third series, after heating up to $400{ }^{\circ} \mathrm{C}$ and treating the sample for 1 hour, i.e. sample T400H1, the product did not exhibit any traces of the precursor probably because the whole of the oxalate had been decomposed already. Employing the approach described above, Mössbauer spectrum of the sample $\mathrm{T} 400 \mathrm{H} 1$ displayed three partially overlapping sextets that could be assigned to a contribution of $\mathrm{Fe}^{3+}$ and $\mathrm{Fe}^{2,5+}$ cations in tetrahedral $(\mathrm{T})$ and octahedral (O) sites of magnetite and maghemite. Based on the XRD analysis four additional sextets were fitted in Mössbauer spectrum and ascribed to iron carbides. Three sextets were assigned the three different sites of iron nuclei in the structure of Hagg's carbide $\left(\mathrm{Fe}_{5} \mathrm{C}_{2}\right)$ whereas the fourth sextet was assigned to cementite $\left(\mathrm{Fe}_{3} \mathrm{C}\right)$. Fitting such small sub-spectra into an overall fit the hyperfine parameters values of sextets corresponding to carbides were strictly fixed to the values previously reported by Malina et al. ${ }^{45}$ Although the inclusion of the carbides sub-spectra into the overall fit was based strictly on the XRD analysis, the carbide sub-spectra corresponded well with the distortions in the background of the spectra e.g. T400H1 spectrum (Figure 2.).

The obtained XRD pattern of T400H1 agreed with the acquired Mössbauer data. Apart from the diffraction peaks that could be assigned to the spinel-structured iron oxide, a small amount of cementite (2.4 wt.\%) and Hagg's carbide, (2.0 wt.\%) were detected. Moreover, three additional small diffraction peaks could be observed at $17^{\circ}, 28^{\circ}$ and $31^{\circ} 2 \theta$ for the sample T400H1. Although some authors ${ }^{15}$ reported these peaks to be an unambiguous sign of maghemite, they might represent a reduction in crystal symmetry of cubic spinel structure driven by partial ordering of vacancies, which is also generated by magnetite non-stoichiometry.
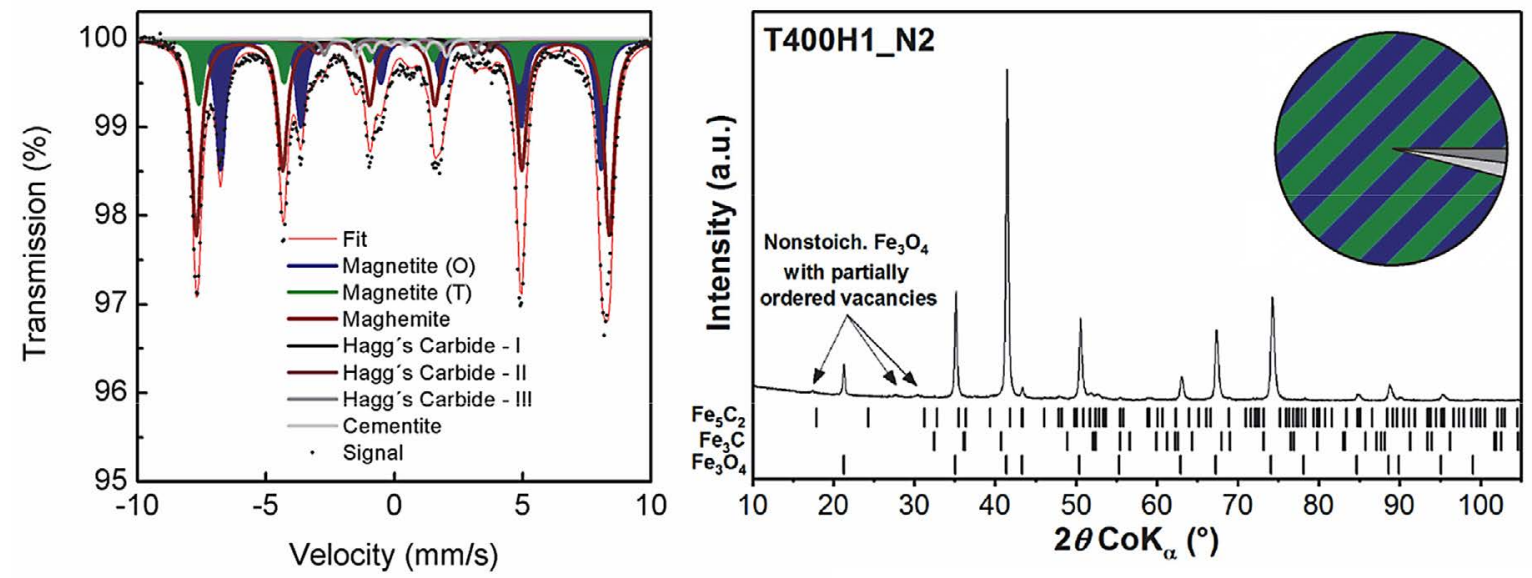

Figure 2. Mössbauer and XRD data of sample T400H1. 


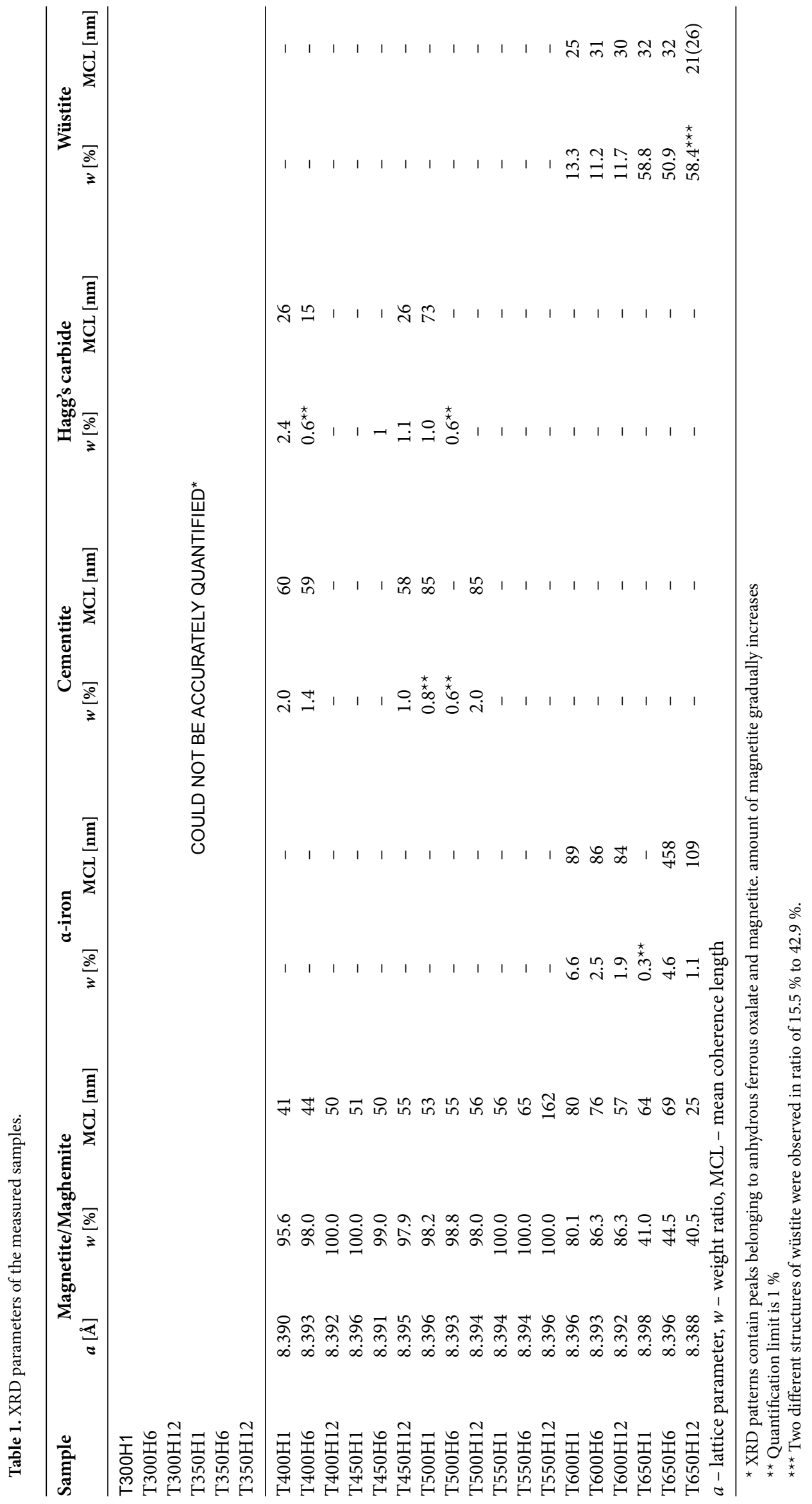

Kopp et al.: Preparation of Magnetite by Thermally Induced ... 
This idea was supported by values of acquired cell parameters (see Table 1.), which reflected the presence of non-stoichiometric magnetite instead of the mixture of magnetite and maghemite. On the other hand, Mössbauer spectrum suggested the presence of maghemite in the sample, as its absence in the spectrum would lead to highly unprobeable reversed magnetite stoichiometry of 1:2 (O:T). Similar results were obtained for the other two remaining spectra of the series T400. The presence of maghemite in the samples due to gradual oxidation of nano-sized magnetite could ex- plain the discrepancies in the results of these two techniques as both measurements were carried out at different time. The crystallite size of iron oxide particles was determined by Rietveld refinement and varied for all the samples in the T400 series between 40 and $50 \mathrm{~nm}$.

\section{4. The T450/T500 Series}

No major changes were observed in the results of the following two series, i.e. T450 and T500 series. The results

Table 2. Mössbauer parameters of the measured samples.

\begin{tabular}{|c|c|c|c|c|c|}
\hline Sample & $\delta \pm 0.01(\mathrm{~mm} / \mathrm{s})$ & $\Delta E_{\mathrm{Q}} \pm 0.01(\mathrm{~mm} / \mathrm{s})$ & $H \pm 0.3(\mathrm{~T})$ & $\mathrm{R} A \pm 2(\%)$ & Site assignment \\
\hline \multirow[t]{2}{*}{ T300H1 } & 1.19 & 2.04 & - & 92 & Ferrous oxalate \\
\hline & 0.33 & 0.45 & - & 8 & SP magnetite \\
\hline \multirow[t]{2}{*}{ T300H6 } & 1.17 & 2.21 & - & 87 & Ferrous oxalate \\
\hline & 0.33 & 0.45 & - & 13 & SP magnetite \\
\hline \multirow[t]{3}{*}{ Т300H12 } & 1.19 & 1.90 & - & 78 & Ferrous oxalate \\
\hline & 0.30 & 0.48 & - & 8 & SP magnetite \\
\hline & 0.18 & - & 43.3 & 14 & Magnetite/Maghemite \\
\hline \multirow[t]{4}{*}{$\mathrm{T} 350 \mathrm{H} 1$} & 1.19 & 2.20 & - & 78 & Ferrous oxalate \\
\hline & 0.25 & - & 48.9 & 5 & Magnetite (site T) \\
\hline & 0.65 & - & 45.7 & 11 & Magnetite (site O) \\
\hline & 0.23 & 0,03 & 49.7 & 5 & Maghemite \\
\hline \multirow[t]{4}{*}{ T350H6 } & 1.16 & 2.24 & - & 12 & Ferrous oxalate \\
\hline & 0.26 & - & 48.9 & 12 & Magnetite (site T) \\
\hline & 0.65 & - & 45.7 & 24 & Magnetite (site O) \\
\hline & 0.33 & 0.02 & 49.7 & 52 & Maghemite \\
\hline \multirow[t]{4}{*}{ T350H12 } & 1.19 & 2.20 & - & 12 & Ferrous oxalate \\
\hline & 0.25 & - & 48.9 & 17 & Magnetite (site T) \\
\hline & 0.65 & - & 45.7 & 34 & Magnetite (site O) \\
\hline & 0.29 & 0.03 & 49.7 & 37 & Maghemite \\
\hline \multirow[t]{7}{*}{$\mathrm{T} 400 \mathrm{H} 1$} & 0.28 & - & 49.1 & 14 & Magnetite (site T) \\
\hline & 0.65 & - & 46.1 & 28 & Magnetite (site O) \\
\hline & 0.32 & 0.02 & 50.0 & 46 & Maghemite \\
\hline & 0.24 & 0.09 & 21.5 & 2 & Hagg's Carbide - I \\
\hline & 0.17 & 0.06 & 18.2 & 3 & Hagg's Carbide - II \\
\hline & 0.22 & 0.13 & 10.9 & 3 & Hagg's Carbide - III \\
\hline & 0.20 & 0.03 & 19.9 & 4 & Cementite \\
\hline \multirow{7}{*}{ T400H6 } & 0.28 & - & 49.1 & 21 & Magnetite (site T) \\
\hline & 0.65 & - & 45.9 & 42 & Magnetite (site O) \\
\hline & 0.31 & 0.02 & 49.7 & 24 & Maghemite \\
\hline & 0.24 & 0.09 & 21.5 & 4 & Hagg's Carbide - I \\
\hline & 0.17 & 0.06 & 18.2 & 5 & Hagg's Carbide - II \\
\hline & 0.22 & 0.13 & 10.9 & 2 & Hagg's Carbide - III \\
\hline & 0.20 & 0.03 & 19.9 & 2 & Cementite \\
\hline \multirow[t]{3}{*}{$\mathrm{T} 400 \mathrm{H} 12$} & 0.28 & - & 48.9 & 27 & Magnetite (site T) \\
\hline & 0.68 & - & 45.7 & 54 & Magnetite (site O) \\
\hline & 0.32 & 0.02 & 49.7 & 19 & Maghemite \\
\hline \multirow[t]{3}{*}{$\mathrm{T} 450 \mathrm{H} 1$} & 0.27 & - & 48.9 & 12 & Magnetite (site T) \\
\hline & 0.65 & - & 45.7 & 25 & Magnetite (site O) \\
\hline & 0.34 & 0.02 & 49.7 & 63 & Maghemite \\
\hline \multirow[t]{3}{*}{ T450H6 } & 0.28 & - & 48.9 & 27 & Magnetite (site T) \\
\hline & 0.67 & - & 45.7 & 54 & Magnetite (site O) \\
\hline & 0.35 & 0.03 & 49.7 & 19 & Maghemite \\
\hline \multirow[t]{4}{*}{$\mathrm{T} 450 \mathrm{H} 12$} & 0.28 & - & 48.9 & 24 & Magnetite (site T) \\
\hline & 0.67 & - & 45.9 & 50 & Magnetite (site O) \\
\hline & 0.31 & 0.03 & 49.7 & 12 & Maghemite \\
\hline & 0.24 & 0.09 & 21.5 & 2 & Hagg's Carbide - I \\
\hline
\end{tabular}




\begin{tabular}{|c|c|c|c|c|c|}
\hline Sample & $\delta \pm 0.01(\mathrm{~mm} / \mathrm{s})$ & $\Delta E_{\mathrm{Q}} \pm 0.01(\mathrm{~mm} / \mathrm{s})$ & $H \pm 0.3(\mathrm{~T})$ & $\mathrm{R} A \pm 2(\%)$ & Site assignment \\
\hline & 0.17 & 0.06 & 18.2 & 2 & Hagg's Carbide - II \\
\hline & 0.22 & 0.13 & 10.9 & 2 & Hagg's Carbide - III \\
\hline & 0.20 & 0.03 & 19.9 & 6 & Cementite \\
\hline \multirow[t]{4}{*}{$\mathrm{T} 500 \mathrm{H} 1$} & 0.26 & - & 48.9 & 24 & Magnetite (site T) \\
\hline & 0.66 & - & 45.7 & 48 & Magnetite (site O) \\
\hline & 0.33 & 0.02 & 49.7 & 18 & Maghemite \\
\hline & 0.20 & 0.03 & 19.9 & 10 & Cementite \\
\hline \multirow[t]{7}{*}{ T500H6 } & 0.27 & - & 49.2 & 24 & Magnetite (site T) \\
\hline & 0.66 & - & 46.1 & 48 & Magnetite (site $\mathrm{O}$ ) \\
\hline & 0.32 & 0.02 & 49.8 & 18 & Maghemite \\
\hline & 0.24 & 0.09 & 21.5 & 3 & Hagg's Carbide - I \\
\hline & 0.17 & 0.06 & 18.2 & 3 & Hagg's Carbide - II \\
\hline & 0.22 & 0.13 & 10.9 & 2 & Hagg's Carbide - III \\
\hline & 0.20 & 0.03 & 19.9 & 2 & Cementite \\
\hline \multirow[t]{7}{*}{$\mathrm{T} 500 \mathrm{H} 12$} & 0.28 & - & 48.9 & 28 & Magnetite (site T) \\
\hline & 0.67 & - & 45.9 & 56 & Magnetite (site O) \\
\hline & 0.28 & 0.02 & 49.7 & 7 & Maghemite \\
\hline & 0.24 & 0.09 & 21.5 & 4 & Hagg's Carbide - I \\
\hline & 0.17 & 0.06 & 18.2 & 3 & Hagg's Carbide - II \\
\hline & 0.22 & 0.13 & 10.9 & 1 & Hagg's Carbide - III \\
\hline & 0.20 & 0.03 & 19.9 & 1 & Cementite \\
\hline \multirow[t]{3}{*}{ T550H1 } & 0.28 & - & 49.1 & 23 & Magnetite (site T) \\
\hline & 0.67 & - & 46.1 & 46 & Magnetite (site O) \\
\hline & 0.30 & 0.02 & -49.7 & 31 & Maghemite \\
\hline \multirow{3}{*}{ Т550H6 } & 0.28 & - & 48.9 & 22 & Magnetite (site T) \\
\hline & 0.66 & - & 45.9 & 43 & Magnetite (site O) \\
\hline & 0.32 & 0.02 & 49.7 & 35 & Maghemite \\
\hline \multirow[t]{3}{*}{ T550H12 } & 0.28 & - & 49.0 & 27 & Magnetite (site T) \\
\hline & 0.67 & - & 45.9 & 54 & Magnetite (site O) \\
\hline & 0.31 & 0.02 & 49.7 & 18 & Maghemite \\
\hline \multirow[t]{5}{*}{$\mathrm{T} 600 \mathrm{H} 1$} & 0.28 & - & 48.9 & 20 & Magnetite (site T) \\
\hline & 0.67 & - & 45.9 & 41 & Magnetite (site O) \\
\hline & 0.26 & 0.02 & 49.7 & 5 & Maghemite \\
\hline & 0.00 & - & 33.0 & 17 & $a-I r o n$ \\
\hline & 1.04 & 0.05 & - & 16 & Wüstite \\
\hline \multirow[t]{5}{*}{ T600H6 } & 0.28 & - & 48.9 & 24 & Magnetite (site T) \\
\hline & 0.67 & - & 46.0 & 48 & Magnetite (site O) \\
\hline & 0.29 & 0.02 & 49.7 & 6 & Maghemite \\
\hline & 0.00 & 0.24 & 32.8 & 7 & $a-I r o n$ \\
\hline & 1.05 & - & - & 14 & Wüstite \\
\hline \multirow[t]{5}{*}{ T600H12 } & 0.28 & - & 48.9 & 22 & Magnetite (site T) \\
\hline & 0.67 & - & 46.1 & 44 & Magnetite (site O) \\
\hline & 0.33 & 0.03 & 49.7 & 15 & Maghemite \\
\hline & 0.00 & - & 33.1 & 5 & a-Iron \\
\hline & 1.03 & 0.25 & - & 14 & Wüstite \\
\hline \multirow[t]{4}{*}{ T650H1 } & 0.27 & - & 49.1 & 14 & Magnetite (site T) \\
\hline & 0.65 & - & 46.0 & 29 & Magnetite (site O) \\
\hline & 0.00 & - & 32.8 & 8 & a-Iron \\
\hline & 1.06 & 0.12 & - & 49 & Wüstite \\
\hline \multirow[t]{4}{*}{ T650H6 } & 0.25 & - & 48.9 & 14 & Magnetite (site T) \\
\hline & 0.65 & - & 45.7 & 28 & Magnetite (site O) \\
\hline & 0.00 & - & 32.8 & 14 & a-Iron \\
\hline & 1.05 & 0.19 & - & 44 & Wüstite \\
\hline \multirow[t]{5}{*}{ T650H12 } & 0.25 & - & 48.9 & 12 & Magnetite (site T) \\
\hline & 0.65 & - & 47.0 & 24 & Magnetite (site O) \\
\hline & 0.00 & - & 32.8 & 5 & a-Iron \\
\hline & 1.04 & 0.27 & - & 40 & Wüstite \\
\hline & 0.86 & 0.72 & - & 20 & Wüstite \\
\hline
\end{tabular}

$\delta$ - isomer shift, $\Delta \mathrm{E}_{\mathrm{Q}}$ - quadrupole splitting, $\mathrm{H}$ - hyperfine magnetic field, $\mathrm{RA}$ - relative area. The f-factor was considered equal to 1 for all reported phases. 
demonstrated similar composition of phases compared to the series T400 (see Table 1. and Table 2.). In both series, the crystallite size of iron oxide particles was slightly higher $(50-56 \mathrm{~nm})$ as excepted due to the increased calcination temperature. A slight rise in the crystallite size was also observed within individual series with prolonged calcination time. Mossbauer spectra displayed three overlapping sextets that could be ascribed to magnetite and maghemite. In some cases, according to XRD analysis, iron carbides were present in the samples and were fitted along in the Mössbauer spectra. However, there was no observed trend in the overall amount of iron carbides in individual samples and some samples of the series did not contain any carbides at all. The presence of carbides in the samples of T400, T450 and T500 series was probably caused by the reducing effect of $\mathrm{CO}$ molecule, which evolve during the decomposition of the oxalate anion. The molecules of $\mathrm{CO}$ then reacted with still undecomposed ferrous oxalate to form iron carbides (1).

$$
8 \mathrm{FeC}_{2} \mathrm{O}_{4}+6 \mathrm{CO} \rightarrow \mathrm{Fe}_{3} \mathrm{C}+\mathrm{Fe}_{5} \mathrm{C}_{2}+19 \mathrm{CO}_{2}
$$

Here, this reaction mechanism, firstly introduced by Hermanek et al., ${ }^{34}$ is modified to accommodate the formation of Hagg's carbide as well. Hong et al ${ }^{46}$ even used the thermal decomposition of ferrous oxalate in dynamic atmosphere of CO to prepare the microcubes of Hagg's carbide for their subsequent application in Fischer-Tropsch synthesis.

Concerning the observed overall amounts of carbides, Hermanek ${ }^{34}$ reported that up to $20 \%$ of iron ions belonged to cementite in Mössbauer spectra, that is higher compared to our results, where only up to $12 \%$ of iron ions was ascribed to iron carbides. In contrast, no carbides were registered in other studies, ${ }^{15,38,39}$ where the conversion gases synthesis route was used for magnetite preparation. In addition, no carbides were also reported in the study by Angermann and Töpfer ${ }^{47}$ who decomposed ferrous oxalate in a combined atmosphere of $\mathrm{CO} / \mathrm{CO}_{2}$. These discrepancies allowed us to conclude that the presence of iron carbides might depend on the partial pressure of $\mathrm{CO}$ inside the cells. The high amount of carbides in Hermanek's study ${ }^{34}$ could be explained by enclosing the sample into a relatively small container, which caused the high partial pressure of the formed $\mathrm{CO}$. When the relatively larger containers were used ${ }^{15,38,39}$ the samples did not contain any iron carbides or their amounts were simply undetectable by the employed instruments. Some of the evolved $\mathrm{CO}$ could also react with the remaining oxygen to form $\mathrm{CO}_{2}$. On the basis of our experimental results, we could suggest that although the sealing of the sample cells prevented the intrusion of the oxygen into the cells, it was not sufficient to withstand the pressure evolved inside during decomposition of the ferrous oxalate. After reaching the critical level of pressure, a part of the gas leaked out and lowered the partial pressure of $\mathrm{CO}$, which might explain the low amount of iron carbides or even their absence in the composition of the samples and the randomness in the carbide's occurrence.

\section{5. The T550 Series}

The next series was calcinated at $550{ }^{\circ} \mathrm{C}$. All three samples of the T550 series were composed of spinelstructured iron oxides according to the data acquired from both Mössbauer spectroscopy and XRD (see Table 1., Table 2.). No signs of carbides or any other material were observed. Although the evaluation of the XRD patterns, especially the cell parameter, pointed to a nonstoichiometric magnetite, the relative areas of individual spectral lines in Mössbauer spectra suggest the presence of maghemite and magnetite mixture, see Figure 3. Compared with our results, Hermanek et al. ${ }^{34}$ also reported a significant amount of $\alpha$-iron (around $20 \%$ in Mössbauer spectrum) in the temperature range of $500-570{ }^{\circ} \mathrm{C}$. They suggested that the $\alpha$-iron was a product of iron carbides decomposition. The missing $\alpha$-iron in our samples might be explained by relatively lower amount of iron carbides. In addition, the eventual traces of $\alpha$-iron might have been
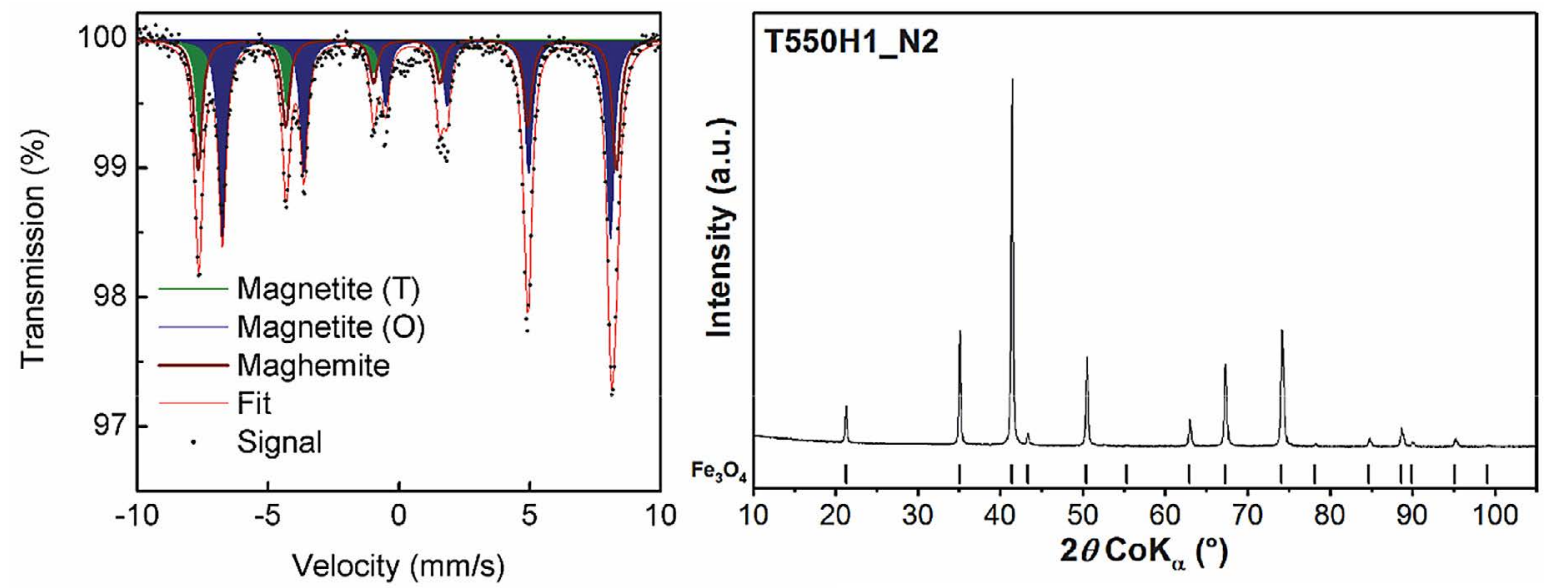

Figure 3. Mössbauer and XRD data of sample T550H1. 


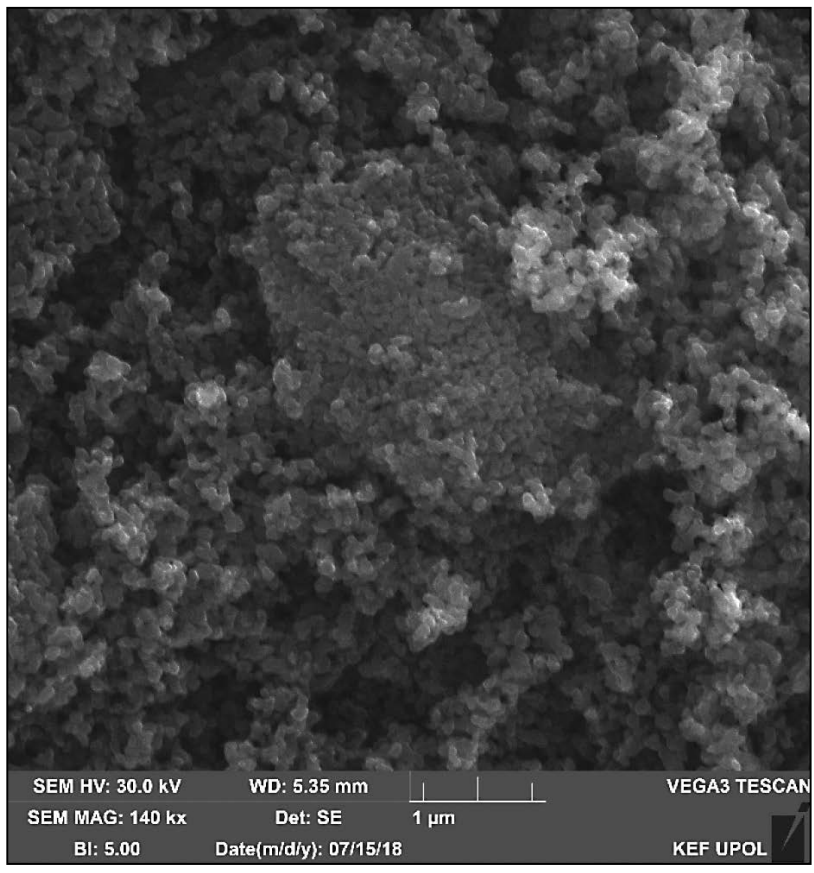

Figure 4. SEM images of samples T550H1 (left) and T550H12 (right).

re-oxidised upon its exposure to the ambient atmosphere after the cells were open. The relatively high temperature of $550{ }^{\circ} \mathrm{C}$ is probably the cause of gradually increasing crystallite size within the series; from $56 \mathrm{~nm}$ to $162 \mathrm{~nm}$ for samples $\mathrm{T} 550 \mathrm{H} 1$ and $\mathrm{T} 550 \mathrm{H} 12$, respectively. The dramatic increase in particle size was also observed in SEM images of samples T500H1 and T550H12 (Figure 4.).

\section{6. The T600 Series}

After the samples of the seventh series had been calcinated at $600{ }^{\circ} \mathrm{C}$, the significant change in Mössbauer spectra was observed. The two sextets which were ascribed to magnetite remained, but they were reduced in area and only a trace amount of maghemite was detected. Additionally, two new components appeared. Firstly, a relatively narrow sextet with hyperfine parameters $\delta=0.0 \mathrm{~mm} / \mathrm{s}$, $H=33.0 \mathrm{~T}$ was identified as a-iron. Secondly, a doublet with a low quadrupole splitting, which was assigned to non-stochiometric wüstite. The exhibition of quadrupole splitting in Mössbauer spectra is a manifestation of the non-equivalent surroundings of iron cations and implies that the observed wüstite phase is non-stoichiometric. The non-stoichiometry of wüstite is generally caused by missing iron cations in its structure. ${ }^{44}$ On the other hand, in some cases it is also possible to fit wüstite component with broad singlet, which suggests it being stochiometric. ${ }^{44}$ The detailed hyperfine parameters obtained for individual samples of the T600 series are listed in Table 2. The results obtained by Mössbauer spectroscopy were in good agreement to those obtained by XRD (Table 1.). All diffraction peaks could be ascribed to magnetite, wüstite and $\alpha$-iron. Such significant change in both Mössbauer spectra and XRD

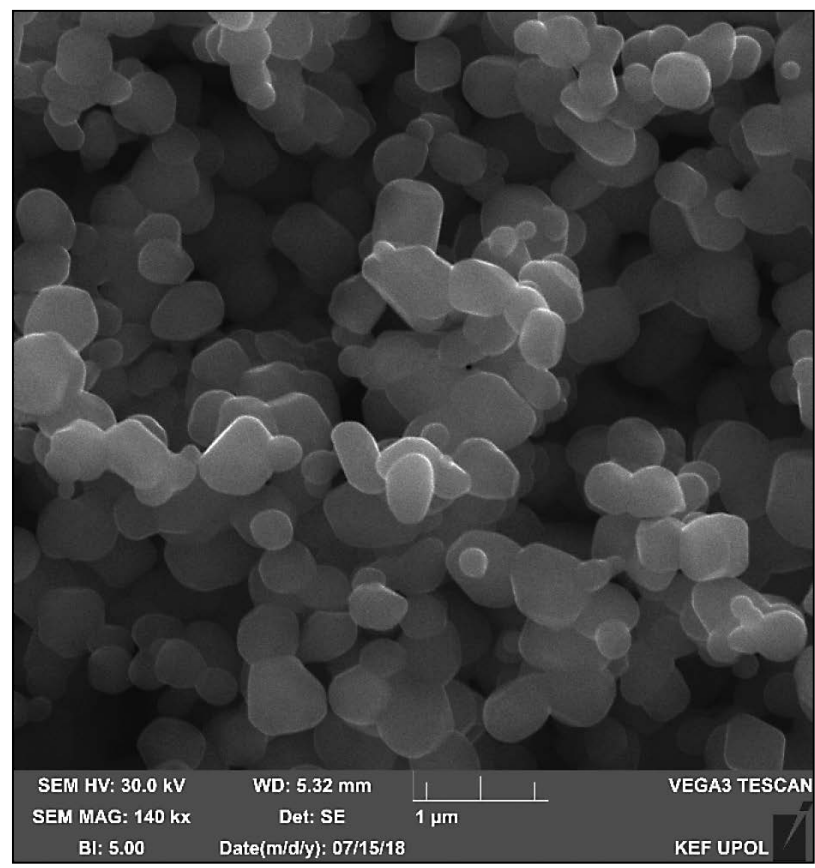

patterns was probably caused by the combination of increased temperature and reducing nature of conversion gases, which resulted in thermally induced reduction of magnetite to wüstite and $\alpha$-iron, as it was suggested by Hermanek et al. ${ }^{34}$ The increase in quadrupole splitting of wüstite phase, which was observed in samples T600H6 and $\mathrm{T} 600 \mathrm{H} 12$, was probably caused by the prolonged exposure of wüstite to high temperature and it could be suggested that this rise was a result of wüstite increasing non-stoichiometry. Similar trend was also observed in the T650 series.

\section{7. The T650 Series}

Evaluation of data acquired for samples of the last T650 series showed very similar composition in comparison to the samples of T600 series. Mössbauer spectra revealed the increased amount of wüstite and decreased amount of $\alpha$-iron and magnetite. An increase in a quadrupole splitting of the wüstite was observed with prolonged calcination, similarly to the previous series. Moreover, the large middle component in the spectrum of the sample T650H12 could not be fitted by only one doublet. Two doublets with following hyperfine parameters were thus ascribed to wüstite in overall $\mathrm{T} 650 \mathrm{H} 12$ spectrum fit, $\delta=1.04 \mathrm{~mm} / \mathrm{s}, \Delta E_{\mathrm{Q}}=0.27 \mathrm{~mm} / \mathrm{s}$ for the first one of the two doublets and $\delta=0.86 \mathrm{~mm} / \mathrm{s}, \Delta E_{\mathrm{Q}}=0.72 \mathrm{~mm} / \mathrm{s}$ for the other one. Concerning the XRD analysis of the sample T650H12, the acquired patterns were composed of two wüstite structures with different cell parameters thus pointing to the presence of two different forms of wüstite. The second wüstite structure was probably the result of the increased non-stoichiometry after the wüstite had been exposed to high temperatures for $12 \mathrm{~h}$. In addition to 

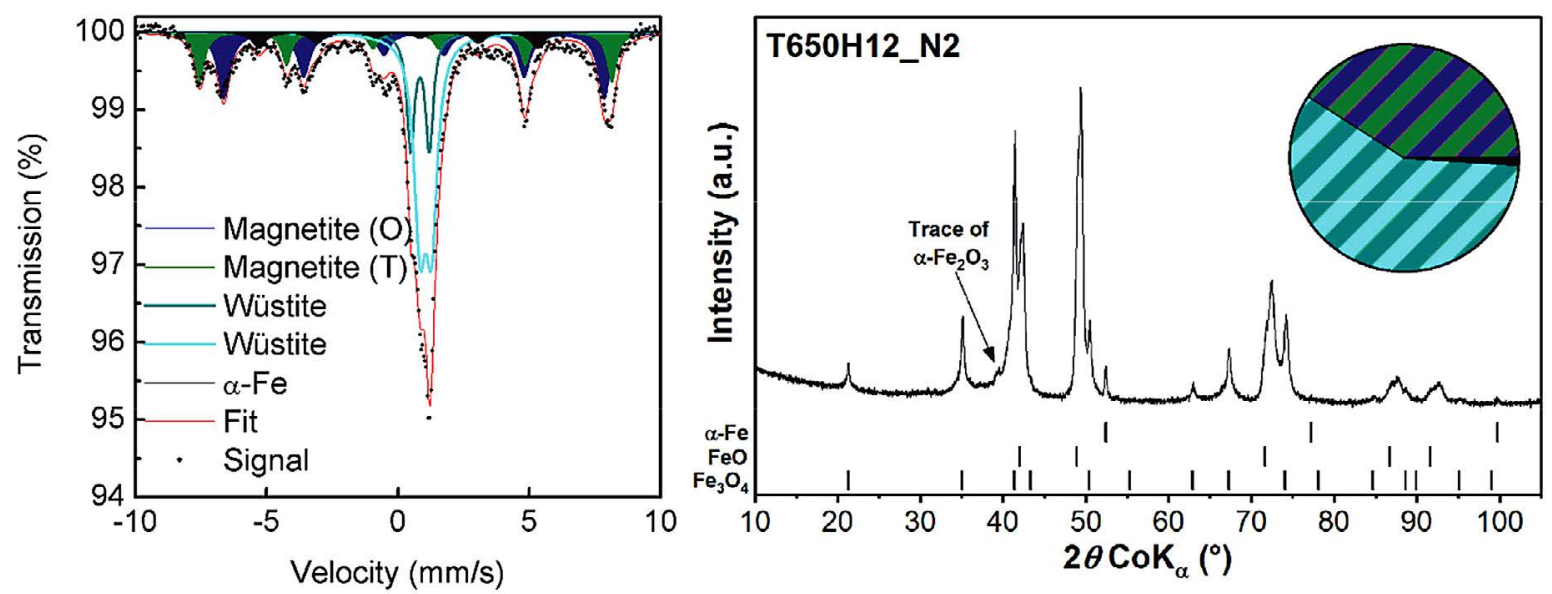

Figure 5. Mössbauer and XRD data of sample T650H12.

quantified phases, part of the $\alpha$-Fe might have been re-oxidised back the most stable iron oxide, i.e., hematite, which was in a trace amount identified in the diffraction pattern of the sample T650H12 (Figure 5.).

\section{Conclusion}

Ferrous oxalate dihydrate was enclosed inside stainless-steel cells under the nitrogen atmosphere. Thermal decomposition of the precursor was systematically carried out at 24 different temperature/time combinations (300$650{ }^{\circ} \mathrm{C} ; 1,6$ and 12 hours) to find the optimal route for magnetite preparation. The prepared materials were studied by Mössbauer spectroscopy and XRD. However, all decomposition routes resulted in obtaining the magnetite particles containing impurities. The remains of the precursor were observed in all the samples calcined below $400^{\circ} \mathrm{C}$, even after long calcination time $(12 \mathrm{~h})$. Almost spinel-structured iron oxide particles, magnetite and maghemite, (e.g. $90 \%)$ were prepared in the temperature range of $400-500^{\circ} \mathrm{C}$. Maghemite was most probably formed by oxidation of small particles of magnetite, which is unstable in the air. Other phases consisted solely of iron carbides phases (i.e., $\mathrm{Fe}_{3} \mathrm{C}$ and $\mathrm{Fe}_{5} \mathrm{C}_{2}$ ). Mixture of magnetite and maghemite, free of carbides, was obtained at $550^{\circ} \mathrm{C}$. Above that temperature the formation of wüstite and $\alpha$-iron was observed. Both of them seemed to be products of thermally induced reduction of magnetite and maghemite by $\mathrm{CO}$. The crystallite size of the obtained iron oxide particles was in the range of 41 to $162 \mathrm{~nm}$, depending on the temperature and the calcination time of the preparation process.

\section{Acknowledgment}

The authors gratefully acknowledge the financial support from the internal IGA grants of Palacký University (IGA_PrF_2019_002 and IGA_PrF_2019_023) and from the Czech-China mobility project Nr. 8H17065 of Ministry of Education, Youth and Sports of the Czech Republic. Authors would also like to thank Mgr. Ivo Medrrík for sharing his expertise and offering a practical advice, Mgr. Tomáš Ingr for SEM images and Helena Sedláčková for her help with the paper.

\section{References}

1. A. S. Teja, P. Y. Koh, Prog. Cryst. Growth Charact. Mater. 2009, 55, 22-45. DOI:10.1016/j.pcrysgrow.2008.08.003

2. A. Ito, M. Shinkai, H. Honda, T. Kobayashi, J. Biosci. Bioeng. 2005, 100, 1-11. DOI:10.1263/jbb.100.1

3. S. Saeidi, N. A. S. Amin, M. R. Rahimpour, J. CO2 Util. 2014, 5, 66-81.

4. M. Zhu, I. E. Wachs, ACS Catal. 2016, 6, 722-732. DOI:10.1021/acscatal.5b02594

5. J. M. Honig, Proc. Indian Acad. Sci. (Chemical Sci.) 1986, 96, 391-409. DOI:10.1007/BF02936294

6. X. Li, Z. Si, Y. Lei, J. Tang, S. Wang, S. Su, S. Song, L. Zhao, H. Zhang, CrystEngComm 2010, 12, 2060-2063.

DOI:10.1039/b926780h

7. S. Komarneni, W. Hu, Y. D. Noh, A. Van Orden, S. Feng, C. Wei, H. Pang, F. Gao, Q. Lu, H. Katsuki, Ceram. Int. 2012, 38, 2563-2568. DOI:10.1016/j.ceramint.2011.11.027

8. S. H. Sun, H. Zeng, J. Am. Chem. Soc. 2002, 124, 8204-8205. DOI:10.1021/ja026501x

9. D. Amara, I. Felner, I. Nowik, S. Margel, Colloids Surfaces A Physicochem. Eng. Asp. 2009, 339, 106-110.

DOI:10.1016/j.colsurfa.2009.02.003

10. J.-N. Park, P. Zhang, Y.-S. Hu, E. W. McFarland, Nanotechnology 2010, 21, 225708 (8).

11. D. Maity, S. G. Choo, J. Yi, J. Ding, J. M. Xue, J. Magn. Magn. Mater. 2009, 321, 1256-1259.

DOI:10.1016/j.jmmm.2008.11.013

12. M. Stefanescu, O. Stefanescu, M. Stoia, C. Lazau, J. Therm. Anal. Calorim. 2007, 88, 27-32.

DOI:10.1007/s10973-006-8003-6 
13. R. Zboril, M. Mashlan, D. Petridis, Chem. Mater. 2002, 14, 969-982. DOI:10.1021/cm0111074

14. E. J. Baran, Chemie der Erde - Geochemistry 2016, 76, 449460.

15. W. Zhou, K. Tang, S. Zeng, Y. Qi, Nanotechnology 2008, 19, 065602 (9).

16. C. Gregor, M. Hermanek, D. Jancik, J. Pechousek, J. Filip, J. Hrbac, R. Zboril, Eur. J. Inorg. Chem. 2010, 2010, 2343-2351.

17. R. Zboril, L. Machala, M. Mashlan, M. Hermanek, M. Miglierini, A. Fojtik, Phys. Status Solidi C Conf. 2004, 1, 3583-3588.

18. N. Koga, Y. Sato, J. Phys. Chem. A 2011, 115, 141-151. DOI:10.1021/jp110407n

19. M. Hermanek, R. Zboril, Chem. Mater. 2008, 20, 5284-5295. DOI:10.1021/cm8011827

20. Y. Feng, T. Hu, Z. Pu, M. Wu, J. Mi, J. Therm. Anal. Calorim. 2015, 122, 947-953. DOI:10.1007/s10973-015-4757-Z

21. L. Yue, R. Liu, D. Jin, Russ. J. eletrochemistry 2015, 51, 299-304.

22. A. K. Ganguli, T. Ahmad, J. Nanosci. Nanotechnol. 2007, 7, 2029-2035. DOI:10.1166/jnn.2007.763

23. P. Hermankova, M. Hermanek, R. Zboril, Eur. J. Inorg. Chem. 2010, 2010, 1110-1118.

24. V. Borker, K. S. Rane, V. N. Kamat Dalal, J. Mater. Sci. 1993, 4, 241-248.

25. D. Smrčka, V. Procházka, P. Novák, J. Kašlík, V. Vrba, AIP Conf. Proc. 2016, 1781, 020012 (8).

26. L. Machala, R. Zboril, A. Gedanken, J. Phys. Chem. B 2007, 111, 4003-4018. DOI:10.1021/jp064992s

27. M. Hermanek, R. Zboril, I. Medrik, J. Pechousek, C. Gregor, J. Am. Chem. Soc. 2007, 129, 10929-10936. DOI: $10.1021 / \mathrm{ja} 072918 \mathrm{x}$

28. V. Rao, A. L. Shashimohan, A. B. Biswas, J. Mater. Sci. 1974, 9 , 430-433. DOI:10.1007/BF00737843

29. M. A. Mohamed, A. K. Galwey, Thermochim. Acta 1993, 213, 269-278. DOI:10.1016/0040-6031(93)80021-2

30. M. E. Mendoza, F. Donado, R. Silva, M. A. Peréz, J. L. Carrillo, J. Phys. Chem. Solids 2005, 66, 927-931.

DOI:10.1016/j.jpcs.2004.06.019
31. E. D. Macklen, J. inorg. nucl. Chem. 1967, 29, 1229-1234. DOI:10.1016/0022-1902(67)80362-2

32. D. Broadbent, D. Dollimore, J. Dollimore, J. Chem. Soc. 1967, 0, 451-454. DOI:10.1039/j19670000451

33. R. A. Brown, S. C. Bevan, J. inorg. nucl. Chem. 1966, 28, 387391. DOI:10.1016/0022-1902(66)80316-0

34. M. Hermanek, R. Zboril, M. Mashlan, L. Machala, O. Schneeweiss, J. Mater. Chem. 2006, 16, 1273-1280.

DOI:10.1039/b514565a

35. M. J. Halsey, A. M. Pritchard, J. Chem. Soc. 1968, 2878-2880. DOI:10.1039/J19680002878

36. M. Katada, T. Ogimoto, J. Radioanal. Nucl. Chem. 2000, 246, 7-14. DOI:10.1023/A:1006744006158

37. M. A. Mohamed, A. K. Galwey, S. A. Halawy, Thermochim. Acta 2005, 429, 57-72. DOI:10.1016/j.tca.2004.08.021

38. T. Plachy, M. Cvek, Z. Kozakova, M. Sedlacik, Smart Mater. Struct. 2017, 26, 025026 (8).

39. Z. Kozakova, I. Kuritka, P. Bazant, M. Pastorek, V. Babayan, Mater. Lett. 2015, 138, 116-119.

DOI:10.1016/j.matlet.2014.09.125

40. J. Pechoušek, D. Jančík, J. Frydrych, J. Navařík, P. Novák, AIP Conf. Proc. 2012, 1489, 186-193. DOI:10.1063/1.4759489

41. J. Pechousek, R. Prochazka, D. Jancik, J. Frydrych, M. Mashlan, J. Phys. Conf. Ser. 2010, 217, 012006 (4).

42. Z. Klencsár, E. Kuzmann, A. Vértes, J. Radioanal. Nucl. Chem. 1996, 210, 105-118. DOI:10.1007/BF02055410

43. G. M. Da Costa, E. De Grave, P. M. A. De Bakker, R. E. Vandenberghe, Clays Clay Miner. 1995, 43, 656-668.

DOI:10.1346/CCMN.1995.0430602

44. R. M. Cornell, U. Schwertmann, The Iron Oxides, 2003.

45. O. Malina, P. Jakubec, J. Kašlík, J. Tuček, R. Zbořil, Nanoscale 2017, 9, 10440-10446. DOI:10.1039/C7NR02383A

46. S. Y. Hong, D. H. Chun, J.-I. Yang, H. Jung, H.-T. Lee, S. Hong, S. Jang, J. T. Lim, C. S. Kim, J. C. Park, Nanoscale 2015, 7, 16616-16620. DOI:10.1039/C5NR04546K

47. A. Angermann, J. Töpfer, J. Mater. Sci. 2008, 43, 5123-5130. DOI:10.1007/s10853-008-2738-3

\section{Povzetek}

V tej študiji predstavljamo raziskavo termičnega razkroja železovega oksalat dihidrata v kombinirani atmosferi inertnih in pretvorbenih plinov, z namenom iskanja optimalne poti za pripravo magnetita. Homogeniziran prekurzor je bil izotermično obdelan v celicah iz nerjavnega jekla pri različnih temperaturah v območju od $300{ }^{\circ} \mathrm{C}$ do $650{ }^{\circ} \mathrm{C}$. Spreminjali smo tudi čas razkroja ( 1 uro, 6 ur in 12 ur). Vzorce smo zaprli v celice s kombinirano atmosfero in s tem odpravili potrebo po pretoku inertnega plina. Strukturne, magnetne in morfološke vidike pripravljenih materialov smo preučili s kombinacijo eksperimentalnih tehnik, kot so Mössbauerjeva spektroskopija, rentgenska praškovna difrakcija in vrstična elektronska mikroskopija (SEM). 